\title{
Application of Electrical Resistivity Tomography Technique for Characterizing Leakage Problem in Abu Baara Earth Dam, Syria
}

\author{
Walid Al-Fares \\ Department of Geology, Atomic Energy Commission, P.O. Box 6091, Damascus, Syria \\ Correspondence should be addressed to Walid Al-Fares; cscientific2@aec.org.sy
}

Received 11 September 2014; Revised 12 November 2014; Accepted 12 November 2014; Published 11 December 2014

Academic Editor: Rudolf A. Treumann

Copyright (C) 2014 Walid Al-Fares. This is an open access article distributed under the Creative Commons Attribution License, which permits unrestricted use, distribution, and reproduction in any medium, provided the original work is properly cited.

\begin{abstract}
Electrical Resistivity Tomography (ERT) survey was carried out at Abu Baara earth dam in northwestern Syria, in order to delineate potential pathways of leakage occurring through the subsurface structure close to the dam body. The survey was performed along two straight measuring profiles of 715 and $430 \mathrm{~m}$ length in up- and downstream sides of the dam's embankment. The analysis of the inverted ERT sections revealed the presence of fractured and karstified limestone rocks which constitute the shallow bedrock of the dam reservoir. Several subsurface structural anomalies were identified within the fractured bedrock, most of which are associated with probable karstic cavities, voids, and discontinuity features developed within the carbonates rocks. Moreover, results also showed the occurrence of a distinguished subsiding structure coinciding with main valley course. Accordingly, it is believed that the bedrock and the other detected features are the main potential causes of water leakage from the dam's reservoir.
\end{abstract}

\section{Introduction}

Water seepage, one of the most common problems of earthen dams, usually occurs either through the reservoir's bedrock or through the embankment-abutment contact. This phenomenon is often related to geological and tectonic factors, for example, faults, fractures, and cavities, or to internal geodynamic and filtration processes in and beneath the dam body [1-7]. Recently, Electrical Resistivity Tomography (ERT) is relatively a new developed geophysical technique, which becomes one of the principle tools widely used in hydrogeological and engineering applications. This technique has proven its performance and adequacy in characterizing the potential paths of water seepage from dams, particularly from earthen ones [8-14].

In Syria, there are more than 160 dams and impounding reservoirs scattered throughout the country. Unfortunately, some of these dams suffer from infiltration or leakage problems related remarkably to different geological and tectonic factors. Abu Baara dam is one of the earthen dams in Syria which suffers from leakage problem. The dam is situated close to Maarin village at the southern margins of Al-Ghab pull-apart developed along the northern parts of the Dead
Sea Fault System (Figure 1). The purpose of the construction of this dam was to save some parts of Al-Ghab plain from rain floods and to meet the area's water needs for irrigation and agricultural development. The embankment of Abu Baara dam has a clayey core surrounded from both sides by filters composed of sands and various mixtures, covered by coarse rockfill to stabilize the dam and protect its clayey core (Figure 2). The $234.5 \mathrm{~m}$ elevated southwest-northeast oriented dam body is $720 \mathrm{~m}$ long and $24.5 \mathrm{~m}$ high at the floor of Abu Baara main valley course. The dam's lake extends over 100 hectares with a maximum dam reservoir storage around 7.6 million cubic meters.

In 1988, the dam reservoir was filled up for the first time with water to inspect the dam before putting it in service. Subsequently, a sharp decrease in stored reservoir water level and water flow from some piezometric boreholes behind the dam body was observed. This phenomenon occurred repeatedly in several subsequent seasons, particularly when the stored dam's lake water level rises. Accordingly, the Directorate of Land Reclamation conducted some geoelectrical surveys (Vertical Electrical Sounding, VES) in many parts of the dam's lake. The results of the geoelectrical surveys showed the presence of an intersection of two faults close to the dam's 


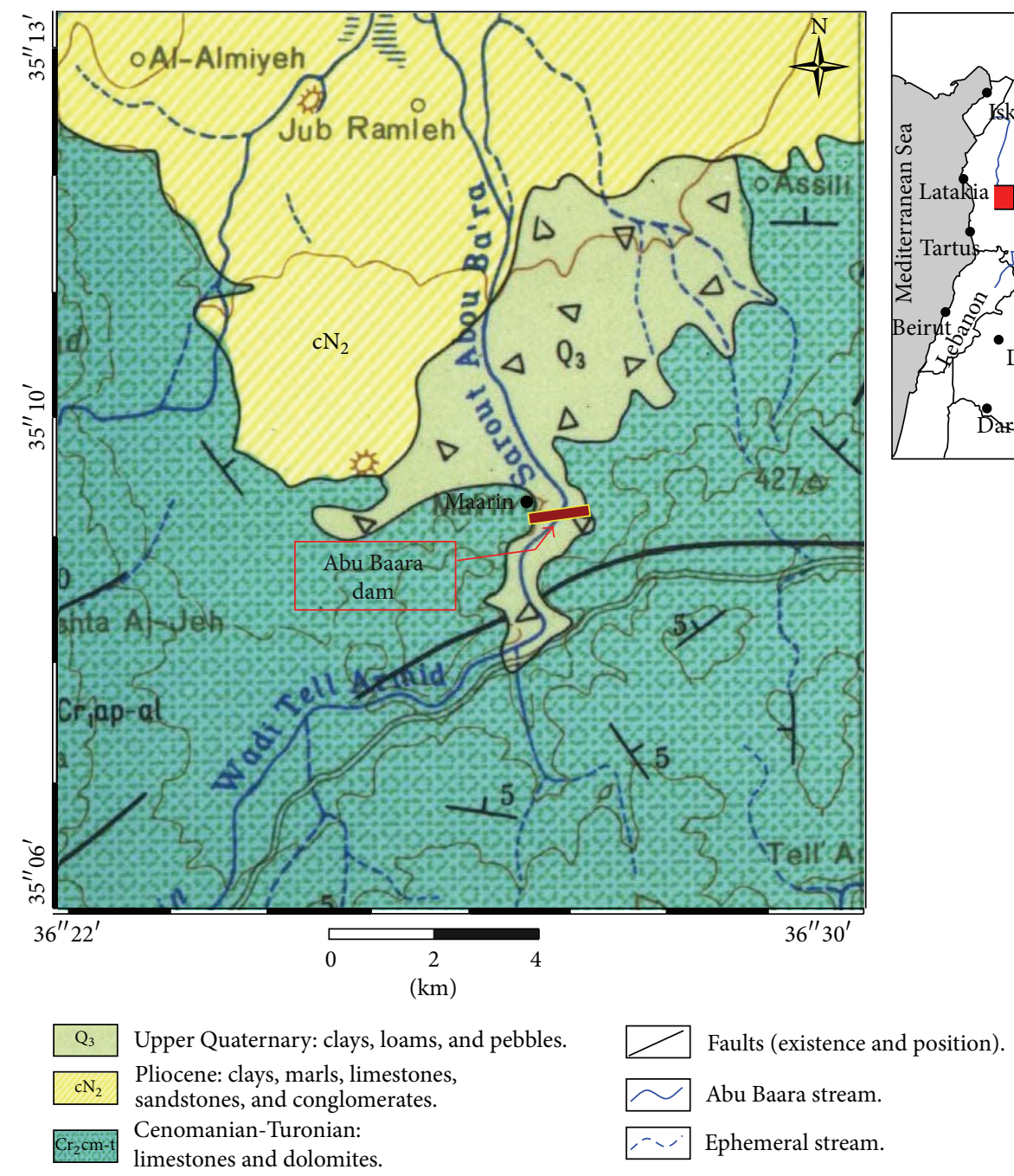

FIGURE 1: Geological map of the study area showing the location of Abu Baara dam, modified from [19].

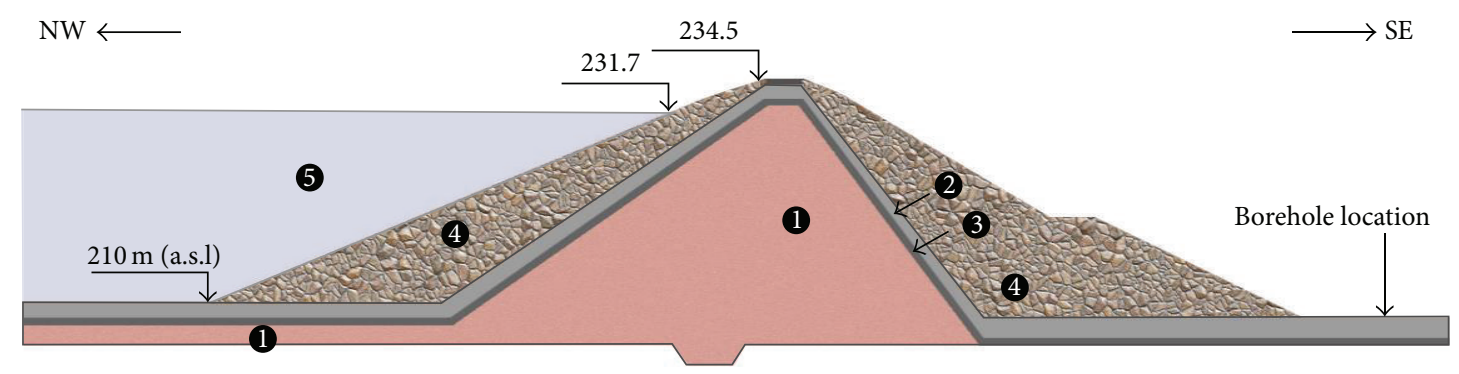

Figure 2: Cross-section in Abu Baara earth dam body, with (1) clay core, (2 and 3) filters, (4) support rockfill, and (5) water reservoir.

main axis and revealed the presence of some karstic caves at depth [15]. Hence, the faulted area was delineated and sealed by a several meters thick clayey layer covering an area of $16,000 \mathrm{~m}^{2}$ approximately. Nevertheless, the water seepage problem from the dam's lake remained unsolved, especially when water level rises high in the reservoir. Therefore, this problem may affect the stability and the safety of dam in the future. Accordingly, this work was proposed with the objective of outlining the subsurface structure of Abu Baara dam's reservoir, delineating weak zones responsible for water seepage and understanding deeply the origin of leakage problem through applying a new developed geophysical technique represented by Electrical Resistivity Tomography (ERT) method close to the dam's embankment downstream. 


\section{Geological and Hydrogeological Settings}

Abu Baara dam is located at the extreme southern margins of Al-Ghab pull-apart basin developed through the ongoing tectonic evolution of the Dead Sea Fault System (DSFS) in northwestern Syria [16-18]. The depression of Al-Ghab basin is filled with more than $100 \mathrm{~m}$ thick Neogene and Quaternary lacustrine and alluvium deposits overlaying uncomfortably deeply seated Cretaceous limestone [19].

As to local geological setting at Abu Baara dam site, the dam's lake floor is composed mainly of Quaternary alluvium clays, sands, and gravels $\left(\mathrm{Q}_{3}\right)$, in addition to carbonatesiliceous cemented conglomerates (Figure 1). The thickness of these deposits varies from one to tens of meters in some places. The alluvial deposits overlay the CenomanianTuronian limestones and dolomites rocks $\left(\mathrm{Cr}_{2} \mathrm{~cm}-\mathrm{t}\right)$ that constitute the bedrock of the dam's reservoir. These rocks, which are dipping towards the main stream by about 515 degrees, are characterized by extensive fracturing and karstification, which contribute to forming cavities, voids, and underground karstic conduits. In addition, the initial geological investigations carried out by the Syrian General Company for Hydraulic Studies revealed the existence of karstified zones developed at various depths within the calcareous rocks in the area. On the other hand, tectonic disturbances such as faults of different trends are marked the carbonates rocks in the region; these faults resulted by various tectonic effects related to the activity of the Dead Sea Faults System (DSFS) in the region.

From a hydrogeological point of view, the CenomanianTuronian limestone and dolomite formations constitute the main groundwater aquifer in the area. The general structure of these aquifer rocks is characterized by high groundwater permeability as a result of the fractured and karstified rocks at various depths. This aquifer is regarded as the principle source for several springs distributed through the region. Besides, most of the local wells drilled in the CenomanianTuronian aquifer are characterized by high productivity. The Quaternary alluvial deposits, which are basically composed of sands, clays, and gravels, represent the second groundwater aquifer in the area. This aquifer is porous and the groundwater level is ranging between 185 and $200 \mathrm{~m}$ (a.s.l.). Generally, the direction of the groundwater flow is from south to north coinciding with the rivers' flow direction in the region. Both aquifers are fed by direct recharge through high rate of rainfall $(700-1000 \mathrm{~mm} / \mathrm{y})$ and drainage networks which are quite common in the area.

\section{Methodology and Instrumentation}

Electrical Resistivity Tomography (ERT) has been widely implemented in the last few years especially in hydrogeology and environmental issues [21-24]. This technique was applied in Abu Baara site to acquire a comprehensive image of the substructure of the dam's reservoir, in order to characterize the leakage problem. For this reason, two straight ERT profiles were carried out in up- and downstream sides, parallel and close to the dam's embankment (Figure 3). The first ERT profile (ERT-P1) is $715 \mathrm{~m}$ in length with $5 \mathrm{~m}$ as an interelectrodes spacing, and the second ERT profile (ERTP2) is $430 \mathrm{~m}$ in length with $2 \mathrm{~m}$ as an interelectrodes spacing. The two profiles were measured during summer season, as the dam's lake was completely dry and empty of water. The ERT measurements were conducted using Syscal Switch72, developed by the French IRIS Instrument. This new instrumentation is equipped with a control unit to execute 2D geoelectrical resistivity sections (multielectrodes), besides traditional geoelectrical soundings (VES, Wenner, and SP). The instrument is composed of a central unit encompassing current transmission unit and potential reception unit (transmitter and receiver units are included in one box), in addition to four special bobbins, multiple switches that enable connecting 72 stainless steel electrodes at once to carry out field measurements.

For executing the ERT profile, 72 electrodes are planted and arranged in straight pattern along the measurements profile. The measuring operation is performed on the basis of special mathematical sequence prepared in advance according to the objective of the measurements. The sequence is built using special software that enables the configuration and interval between the electrodes to be preselected. Consequently, the investigation depth and configuration of the measurement can be determined. The collected data are automatically stored in the instrument's memory using SchlumbergerWenner sequence with an interelectrodes spacing of 2 and $5 \mathrm{~m}$. Thereby, the investigation depth in this case ranges between 20 and $45 \mathrm{~m}$, including 759 measuring points distributed at 16 depth levels. In order to perform a long ERT profile, it is necessary to adopt and use several RollAlong Sequences compatible with the standard sequence that should be consistent in terms of configuration and electrodes interval. The Roll-Along Sequence of 36 electrodes includes 304 additional measuring points. Finally, the stored raw data are transported to PC for treatment and interpretation using $2 \mathrm{D}$ inversion software. The coordinates of profile points were determined using GPS with UTM projection. A topographic survey has been also conducted along the ERT profile length.

\section{Results}

The obtained results, based on 2D inversion of the ERT field data, were interpreted in order to characterize the subsurface structure within the penetrated investigation depth. The ERT profiles were carried out 10 meters away from the dam's body at up- and downstream sides. The two profiles start from the dam's embankment southwestern edge towards the northeastern end (Figure 3). The collected ERT data were inverted using the least-squares method including smoothing of model resistivity to obtain better results from noisy data. The optimization of this method essentially depends on reducing the difference between the measured and calculated apparent resistivity values. This difference is expressed by root mean squared (RMS) error.

The ERT field data were collected along ERP-P1 and ERT$\mathrm{P} 2$ profiles. The data were inverted using RES2DINV software developed by Loke and Barker in 1996 [25]. Figures 4 and 6 


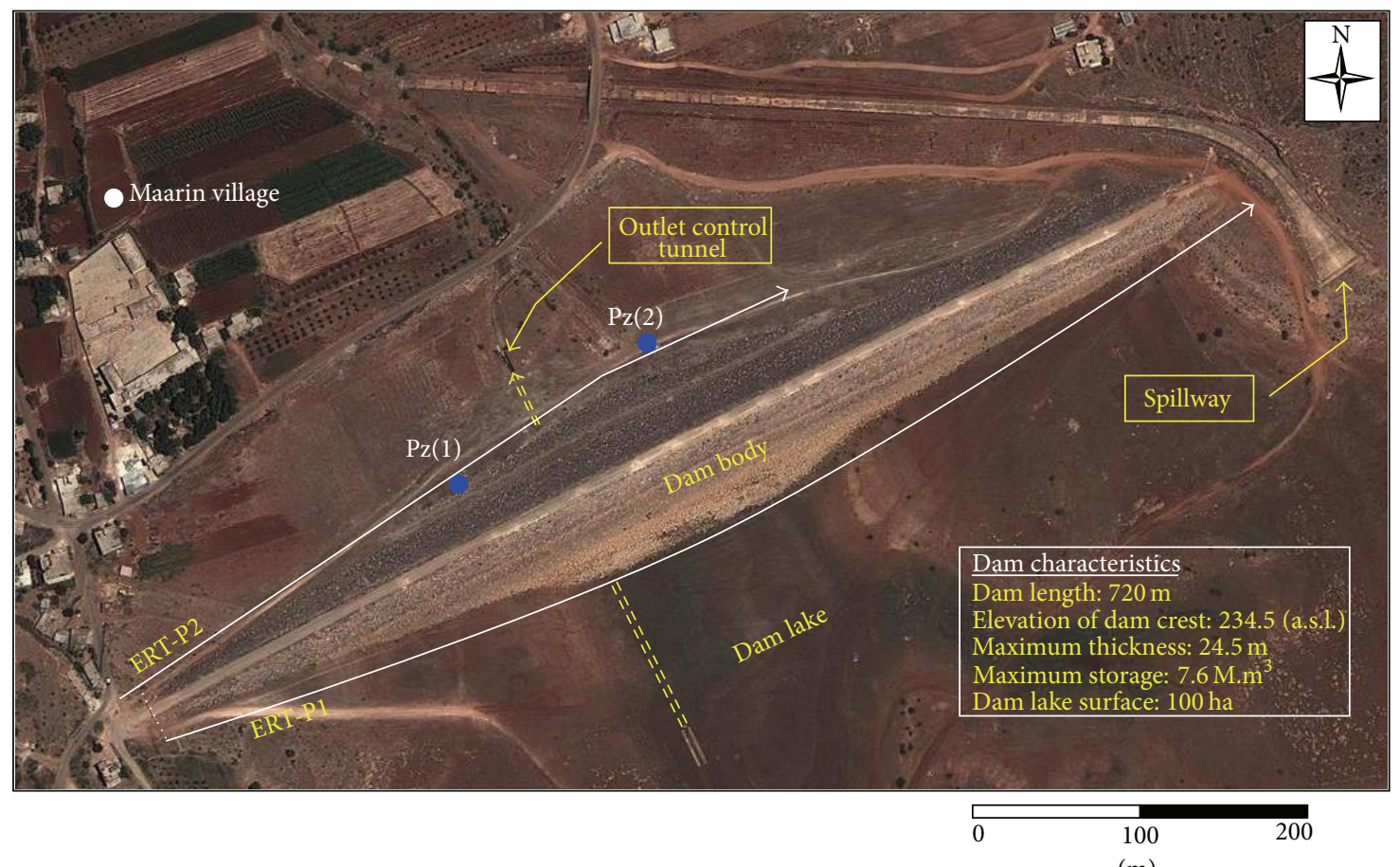

(m)

FIGURE 3: Locations of the ERT profiles realized at up- and downstream sides of Abu Baara dam; $\mathrm{Pz}(1)$ and $\mathrm{Pz}(2)$ : piezometric boreholes located behind the dam body.

show the complete set of the geoelectrical images of the measured and the calculated apparent resistivity pseudosections as well as the inverted resistivity model of the ERT profiles. The geoelectrical ERT-P1 section includes a thin layer of alluvial deposits which covers the first third of the section. The center part of the section is completely composed of the alluvial deposits to more than $45 \mathrm{~m}$ depth. At the last third of the section, the thickness of this layer gradually decreases until the end of the section. The alluvial deposits overly hard and fractured limestones rocks which constitute the bedrock of the dam reservoir floor. Several abnormal features such as cavities, voids, and fractures were identified, along the ERT section, within the limestone bedrock. These features could be considered as anomalous structures that almost play a significant role in the leakage processes from the dam reservoir. The ERT-P2 profile was conducted in upstream side of the embankment of the dam. The start point of this ERT-P2 profile is located at $20 \mathrm{~m}$ before the beginning of the ERT-P1 as illustrated in Figure 2. The difference between the start points of the two profiles is related to the accessibility and possibility of performing the field measurements. The general structure of the ERT-P2 section seems to be similar to the previous ERT-P1 section from where it includes a superficial layer of alluvial deposits and cover hard fractured limestones layer. The depth of this section is about $20 \mathrm{~m}$ due to the $2 \mathrm{~m}$ interelectrodes separation used. This profile was implemented in order to obtain more details of substructures behind the dam body. The resistivity values of the various geological structures and anomalies features, which have been detected by the ERT sections, are shown in Table 1.

\section{Interpretation of ERT Sections}

The inverted resistivity model represents the subsurface resistivity values of the geological formations of the dam's lake floor close to the dam body. The results obtained, which are based on the $2 \mathrm{D}$ inversion of the field data, were interpreted to characterize the shallow bedrock and other subsurface features in the site with the aid of the available lithological boreholes information.

5.1. ERT-P1. Figure 4 illustrates the geoelectrical ERT-P1 section, which can be divided into three main blocks horizontally differentiated as follows.

Block I. This block extends from the beginning of the ERT-P1 profile to a distance of $300 \mathrm{~m}$ of the section. It is composed of a $7 \mathrm{~m}$ thick surficial layer in average, with resistivity values ranging between 50 and $150 \Omega \cdot \mathrm{m}$, corresponding with Quaternary alluvium of clays, sands, and gravels, covering the dam's lake floor. The alluvial deposits overlay gently dipping (5-7 ${ }^{\circ}$ valley-inward) Cenomanian-Turonian hard fractured limestone rocks. These rocks, which are characterized by high resistivity values varying between 300 and $1000 \Omega \cdot \mathrm{m}$, constitute the main shallow bedrock of the dam's lake. A distinctive resistivity anomaly has been recognized within a distance interval of 60-90 m measured from the ERT-P1 section start point. This anomaly is distinguished by high electrical resistivity values exceeding $1200 \Omega \cdot \mathrm{m}$. It is believed that this anomaly almost is attributed to a karstic cavity developed within the limestone rocks by the influence of 


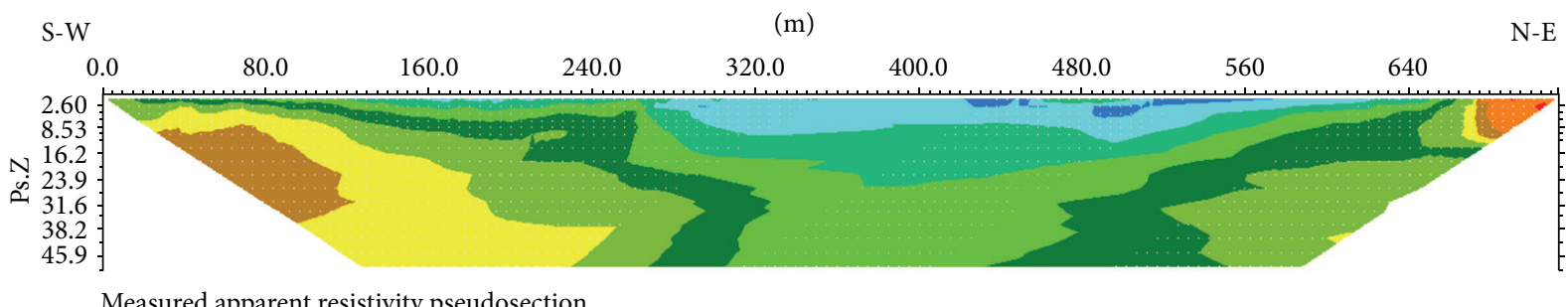

(a)

(m)

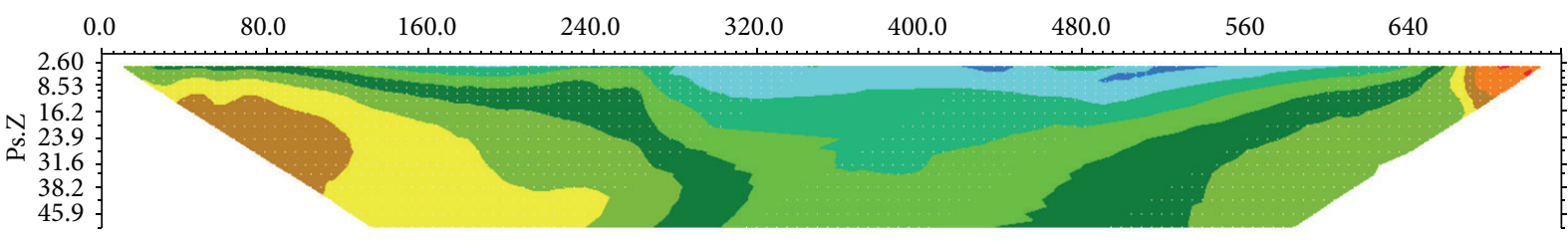

Calculated apparent resistivity pseudosection

(b)

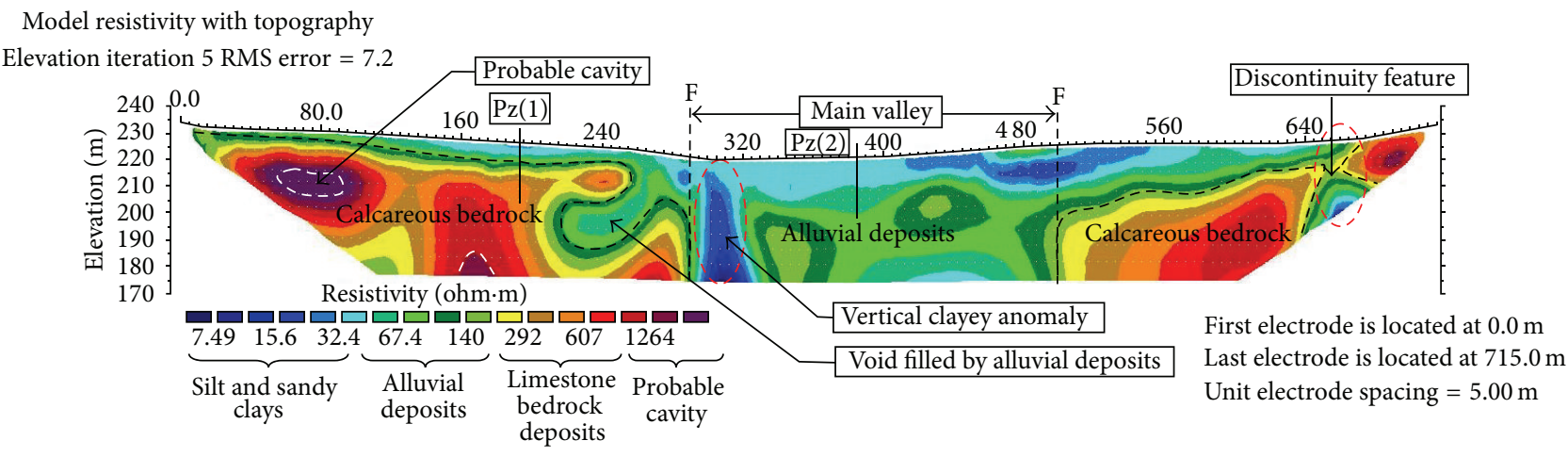

(c)

FIGURE 4: Interpretation of the geoelectrical section of the ERT-P1 profile carried out in downstream of Abu Baara dam: (a) pseudosection of the measured apparent resistivity, (b) pseudosection of the calculated apparent resistivity, and (c) interpretation of the inverted ERT section with topography; $\mathrm{Pz}(1)$ and $\mathrm{Pz}(2)$ : piezometric boreholes locations drilled behind the dam body.

the groundwater flow in the area. The presence of a karstic cavity near the surface and close to the dam body certainly represents a suitable pathway for water leakage especially when it has lateral and vertical extensions and when the stored water goes up to high levels (more than $220 \mathrm{~m}$ a.s.l.). On the other hand, the appearance of a cavity close to the dam body apparently poses a threat to the safety and stability of the dam. Another anomalous feature is observed within a distance interval of 230-250 m measured from the ERT-P1 profile start point. This feature is likely to be attributed to an open void filled by moderate resistivity alluvial deposits values (less than $150 \Omega \cdot \mathrm{m}$ ). This void could result by the effect of karstification processes or dissolution of the carbonates rocks. Furthermore, the geological description of these block rocks is compatible with the lithological borehole log $\mathrm{Pz}(1)$ drilled upstream the dam (Figure 5), whose lithological column is completely composed of hard fractured limestones. Consequently, most of the detected features within this block form favorable zones for water leakage from the dam's reservoir.
TABLE 1: Resistivities values of the detected subsurface features derived from the interpreted ERT sections.

\begin{tabular}{lcc}
\hline Number & Structures and features & Resistivity $\Omega \cdot \mathrm{m}$ \\
\hline 1 & Silty and sandy clays & $5-30$ \\
2 & Alluvium and gravels deposits & $50-150$ \\
3 & Limestones and dolomites bedrock & $300-1000$ \\
4 & Cavity & $1000-1300$ \\
5 & Void filled by alluvial deposits & $50-150$ \\
6 & Vertical clayey anomaly & $5-15$ \\
7 & Fractures (discontinuity feature) & - \\
\hline
\end{tabular}

Block II. This block forms the central part of the ERT-P1 profile coinciding with the main valley course and stretching over a distance interval of 300 to $500 \mathrm{~m}$ measured from the ERT section start point (Figure 4). The $200 \mathrm{~m}$ long block is sharply limited by two abrupt vertical edges, likely interpreted as faults or fractures that resulted by tectonic 

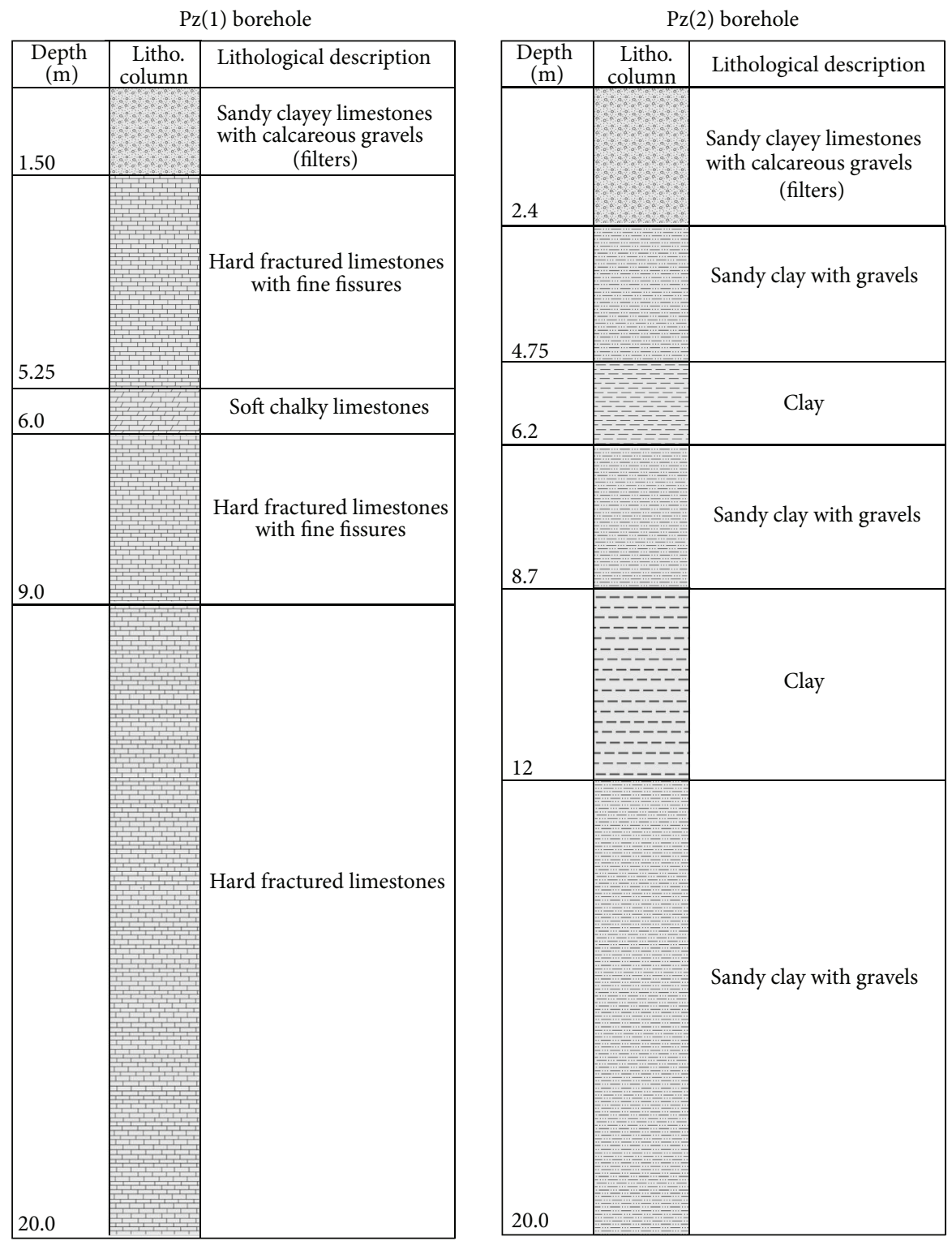

FIgURE 5: Comparison between lithological logs of the boreholes $\mathrm{Pz}(1)$ and $\mathrm{Pz}(2)$ drilled directly behind the dam body, modified after [20].

activity responsible for faulting and subsiding. From geological and tectonic point of view, block II forms a $200 \mathrm{~m}$ wide small graben structure coinciding with the main Abu Baara valley. The structure is filled later by Quaternary alluvium sediments, whose electrical resistivity values range between 50 and $150 \Omega \cdot \mathrm{m}$ and thickness likely exceeds the $50 \mathrm{~m}$ preset investigation depth. On the other hand, the lithological section of this block is corresponding to a large extent with the lithological borehole column $\mathrm{Pz}(2)$, which is composed completely of clays and sandy clays (Figure 5). The comparison between the $\mathrm{Pz}(1)$ lithological column, completely composed of hard fractured limestones, and the $\mathrm{Pz}(2)$ column, completely composed of sandy clays, and the sharp contact between blocks (I) and (II) indicate strongly the presence of a fault contact between them controlling the Abu Baara valley course. Moreover, a $20 \mathrm{~m}$ wide wedge-like anomaly is also recognized in ERT-P1 image adjacent to the block II left edge. This anomaly is interpreted as an abnormal vertical wedge filled by clays. It could probably result by vertical water movement downcutting through the karstic limestone. Accordingly, it is quite clear that this block is considered as the most important and significant segment of the ERT-P1 section, since infiltration and water losses most likely occur along the faulted contact zones between alluvium and hard limestone.

Block III. It extends over the last 500-715 m distance interval of the ERT-P1 section. Quaternary alluvium thickness layer increases the valley inward to exceed $25 \mathrm{~m}$, and its resistivity values as mentioned above vary between 50 and $150 \Omega \cdot \mathrm{m}$. The alluvial deposits cover hard limestone rocks with highresistivity $(300-1000 \Omega \cdot \mathrm{m})$, which are dipping $20^{\circ}$ towards 


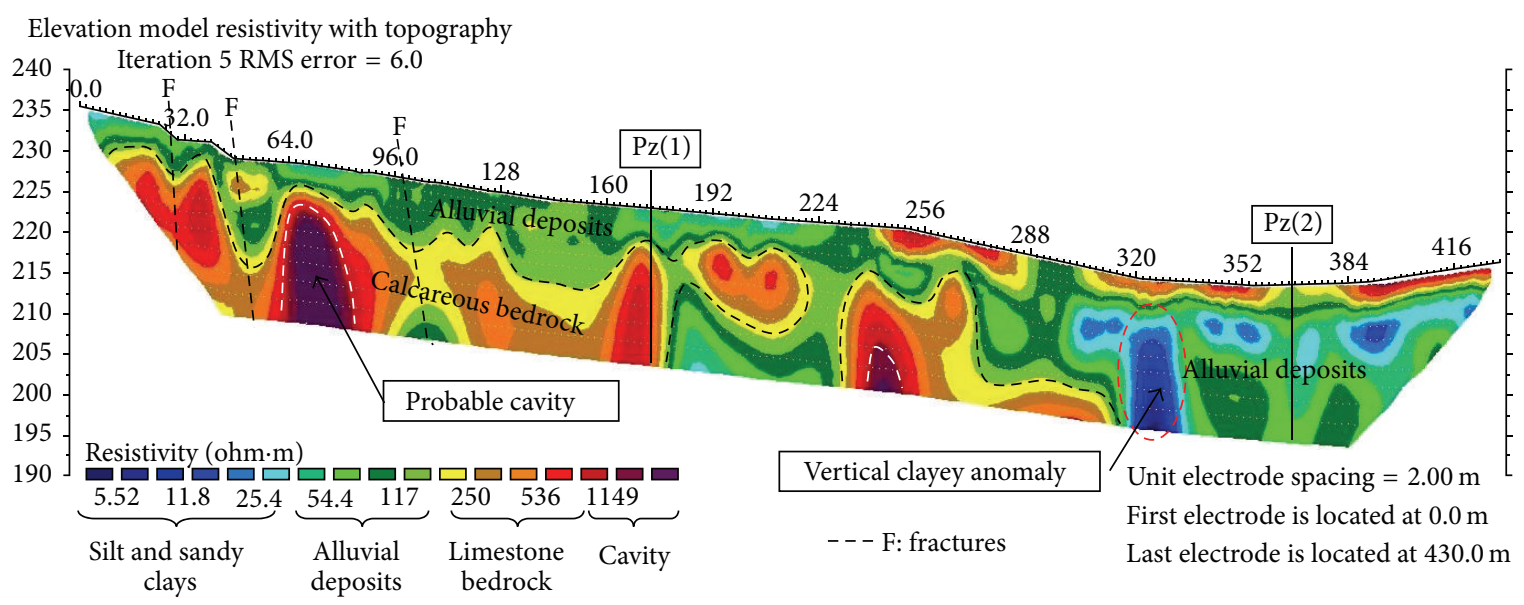

FIGURE 6: Interpretation of the geoelectrical section of the ERT-P2 profile carried out in upstream of $\mathrm{Abu} \mathrm{Baara}$ dam, where $\mathrm{Pz}(1)$ and $\mathrm{Pz}(2)$ are piezometric boreholes.

the main valley. An abrupt discontinuity feature is observed close to the end of the ERT section (at $650 \mathrm{~m}$ distance measured from profile start eastward), corresponding with a vertical fracture in limestone. It widens downwards and is filled with low resistivity alluvial deposits. The discontinuity feature represents an additional probable factor for water seepage from the dam's lake.

5.2. ERT-P2. This profile is situated behind the dam body and extends along a distance of $430 \mathrm{~m}$. Figure 6 illustrates the inverted resistivity section of the ERT-P2 profile. The geometry and general structure of the detected geological features revealed by the geoelectrical ERT-P2 section are similar to what was found in the previous ERT-P1 section, but in more detail due to the use of $2 \mathrm{~m}$ as interelectrodes spacing rather than $5 \mathrm{~m}$. The alluvial deposits layer, which is composed of clays, sands, and gravel, covers the superficial parts of the profile and it seems to be irregular with regard to the thickness. This is due to the irregularity of the eroded surface of the underlying limestone bedrock. The second layer is related to the hard and fractured limestone bedrock (300-1000 $\Omega \cdot \mathrm{m})$, which forms the basement of the dam lake. Several subvertical fractures could be identified along this bedrock. The cavity and the vertical clayey anomalies, which appeared in the previous ERT-P1 section, are also presented in the ERT-P2 section (Figures 5 and 6). This finding confirms the existence of these anomalous features in the subsurface geological structure near to the dam body. Furthermore, the presence of these abnormal features in both ERT sections proves that these features have lateral extensions passing underneath the dam embankment. Additionally, the appearance of the detected cavity in both sides of the dam indicates clearly that it is most likely related to underground karstic conduit, and this explains the sharp decreasing in water level in the lake when it reaches levels more than $220 \mathrm{~m}$ (a.s.l.). All these factors which include the eroded and fractured bedrock, cavities, and fractures are certainly enhancing the leakage processes throughout the dam reservoir.
Table 2 summarizes the interpretation of the ERT sections and describes the characteristics of the detected subsurface features and indicates the possible locations of water leakage from the dam's reservoir close to the embankment of the dam.

\section{Conclusion}

The results obtained by the application of the Electrical Resistivity Tomography (ERT) confirm the ability of this technique to delineate some critical geological subsurface structures such as faults, fractures, cavities, and discontinuity features.

The analysis of the ERT sections performed close to the embankment in up- and downstream of Abu Baara dam revealed three main blocks horizontally differentiated forming the subsurface structure of the dam's reservoir. The first and the third blocks consisted of an uppermost layer composed of Quaternary alluvial deposits of clays, sands, and gravels. The alluvial deposits layer covers fractured and karstified limestone rocks, characterized by the presence of cavities, voids, and tectonic discontinuities. These rocks constitute main subsurface bedrock of the dam lake floor, whereas the second block is bounded by two fractures representing the central subsiding block of a small graben developed into Abu Baara main valley. The lithological substructures revealed by the ERT sections are compatible with the lithological columns of the two piezometric boreholes drilled behind the dam body and confirm the presence of faults or fractures, which control Abu Baara main valley course. Eventually, it is evident that the fractured and karstified limestone bedrock including cavities and fractures, which underlay the reservoir, is the main causative factor responsible for the leakage in the Abu Baara dam.

\section{Conflict of Interests}

The author declares that there is no conflict of interests regarding the publication of this paper. 


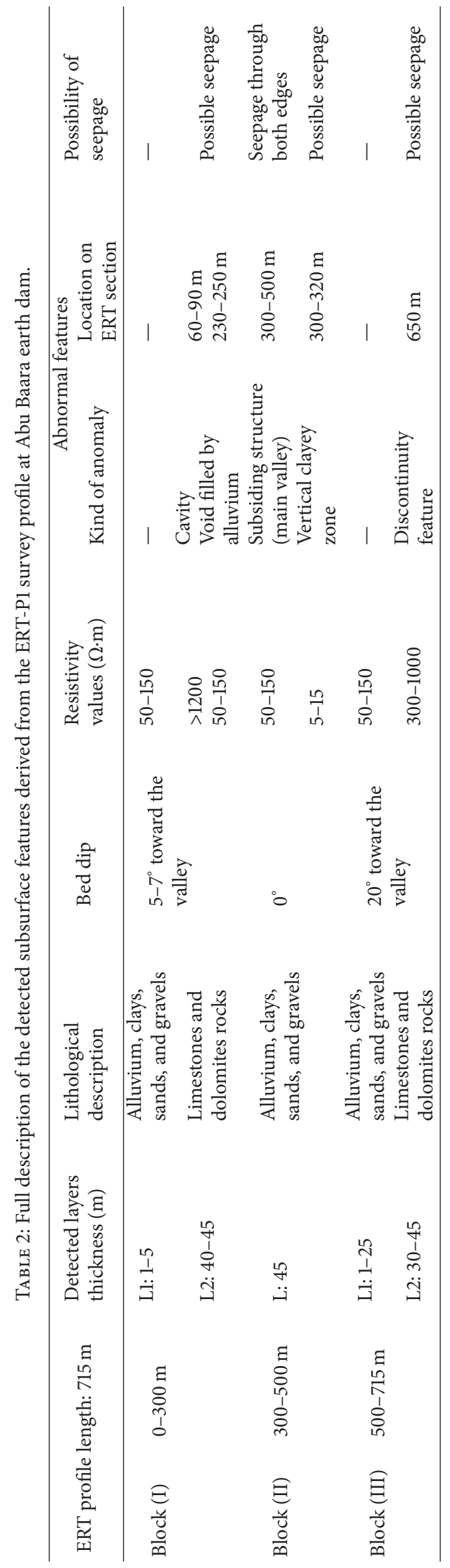




\section{Acknowledgments}

The author would like to thank Professor I. Othman, Director General of the Atomic Energy Commission of Syria (AECS), for his encouragement and constant support. Thanks are also due to Dr. Z. Kattan, Head of the Geology Department, and to the author's colleagues M. Al-Hilal and Y. Radwan for reading and improving the paper. Thanks also are due to Dr. S. AlDiab and E. Soliman for their help in the field.

\section{References}

[1] S. Johansson and T. Dahlin, "Seepage monitoring in an earth embankment dam by repeated resistivity measurements," European Journal of Environmental and Engineering Geophysics, vol. 1, no. 3, pp. 229-247, 1996.

[2] T. V. Panthulu, C. Krishnaiah, and J. M. Shirke, "Detection of seepage paths in earth dams using self-potential and electrical resistivity methods," Engineering Geology, vol. 59, no. 3-4, pp. 281-295, 2001.

[3] M. A. J. Bakker, D. Maljers, and H. J. T. Weerts, "Groundpenetrating radar profiling on embanked floodplains," Netherlands Journal of Geosciences, vol. 86, no. 1, pp. 55-61, 2007.

[4] S. Oh and C.-G. Sun, "Combined analysis of electrical resistivity and geotechnical SPT blow counts for the safety assessment of fill dam," Environmental Geology, vol. 54, no. 1, pp. 31-42, 2008.

[5] P. Sjödahl, T. Dahlin, S. Johansson, and M. H. Loke, "Resistivity monitoring for leakage and internal erosion detection at Hällby embankment dam," Journal of Applied Geophysics, vol. 65, no. 3-4, pp. 155-164, 2008.

[6] J. Asfahani, Y. Radwan, and I. Layyous, "Integrated geophysical and morphotectonic survey of the impact of Ghab extensional tectonics on the Qastoon Dam, Northwestern Syria," Pure and Applied Geophysics, vol. 167, no. 3, pp. 323-338, 2010.

[7] P. A. Bedrosian, B. L. Burton, M. H. Powers, B. J. Minsley, J. D. Phillips, and L. E. Hunter, "Geophysical investigations of geology and structure at the Martis Creek Dam, Truckee, California," Journal of Applied Geophysics, vol. 77, pp. 7-20, 2012.

[8] A. Aina, M. O. Olorunfemi, and J. S. Ojo, "An integration of aeromagnetic and electrical resistivity methods in dam site investigation," Geophysics, vol. 61, no. 2, pp. 349-356, 1996.

[9] A. T. Batayneh, A. S. Al Zoubi, and A. A. Abueladas, "Geophysical investigations for the location of a proposed dam in Al Bishriyya (Al Aritayn) area, northeast Badia of Jordan," Environmental Geology, vol. 40, no. 7, pp. 918-922, 2001.

[10] I.-K. Cho and J.-Y. Yeom, "Crossline resistivity tomography for the delineation of anomalous seepage pathways in an embankment dam," Geophysics, vol. 72, no. 2, pp. G31-G38, 2007.

[11] I. B. Osazuwa and C. E. Chii, "A two-dimensional electrical resistivity imaging of an earth dam, Zaria," Nigeria Journal of Environmental Hydrology, vol. 17, no. 28, pp. 1-8, 2009.

[12] W. Al-Fares, "Contribution of the geophysical methods in characterizing the water leakage in Afamia B dam, Syria," Journal of Applied Geophysics, vol. 75, no. 3, pp. 464-471, 2011.

[13] S. Thompson, B. Kulessa, and A. Luckman, "Integrated electrical resistivity tomography (ERT) and self-potential (SP) techniques for assessing hydrological processes within glacial lake moraine dams," Journal of Glaciology, vol. 58, no. 211, pp. 849-858, 2012.
[14] A. D. Chinedu and A. J. Ogah, "Electrical resistivity imaging of suspected seepage channels in an earth dam in Zaria, NorthWestern Nigeria," Open Journal of Applied Sciences, vol. 3, no. 1, pp. 145-154, 2013.

[15] S. Al-Diab, "Report of geophysical investigations executed under the technical conditions proposed by EDF to estimate the technical situation of Abu Baara dam," Internal Report, 2008.

[16] G. Brew, Tectonic evolution of Syria interpreted from integrated geophysical and geological analysis [Ph.D. thesis], Cornell University, Ithaca, NY, USA, 2001.

[17] F. Gomez, M. Khawlie, C. Tabet, A. N. Darkal, K. Khair, and M. Barazangi, "Late Cenozoic uplift along the northern Dead Sea transform in Lebanon and Syria," Earth and Planetary Science Letters, vol. 241, no. 3-4, pp. 913-931, 2006.

[18] S. Hamade and C. Tabet, "The impacts of climate change and human activities on water resources availability in the Orontes watershed: case of the Ghab region in Syria," Journal of Water Sustainability, vol. 3, no. 1, pp. 45-59, 2013.

[19] V. Ponikarov, The Geological Map of Syria, Hama-Latheqieh Sheet, Scale 1:1200,000, V.O. Technoexport, Ministry of Industry, Damascus, Syria, 1966.

[20] General Company of Hydraulic Studies in Syria, "Technical report about the geological and geophysical investigations in Abu Baara dam," Internal Report, 2008.

[21] W. J. Seaton and T. J. Burbey, "Evaluation of two-dimensional resistivity methods in a fractured crystalline-rock terrane," Journal of Applied Geophysics, vol. 51, no. 1, pp. 21-41, 2002.

[22] S. R. Wilson, M. Ingham, and J. A. McConchie, "The applicability of earth resistivity methods for saline interface definition," Journal of Hydrology, vol. 316, no. 1-4, pp. 301-312, 2006.

[23] M. Lazzari, A. Loperte, and A. Perrone, "Near surface geophysics techniques and geomorphological approach to reconstruct the hazard cave map in historical and urban areas," Advances in Geosciences, vol. 24, pp. 35-44, 2010.

[24] J. Zhu, J. C. Currens, and J. S. Dinger, "Challenges of using electrical resistivity method to locate karst conduits-a field case in the Inner Bluegrass Region, Kentucky," Journal of Applied Geophysics, vol. 75, no. 3, pp. 523-530, 2011.

[25] M. H. Loke and R. D. Barker, "Rapid least-squares inversion of apparent resistivity pseudosections by a quasi-Newton method," Geophysical Prospecting, vol. 44, no. 1, pp. 131-152, 1996. 

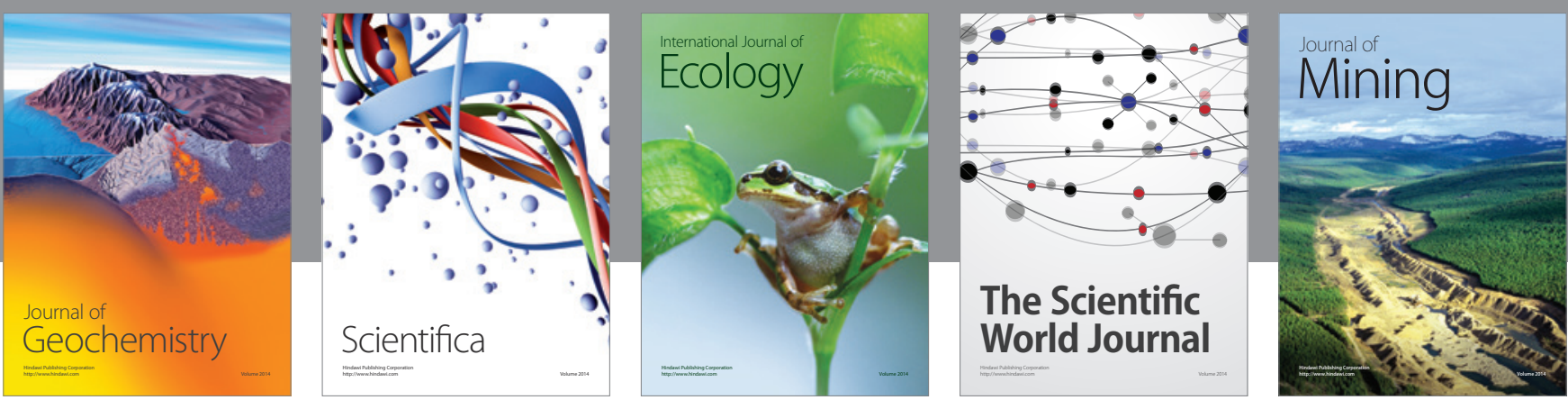

The Scientific World Journal
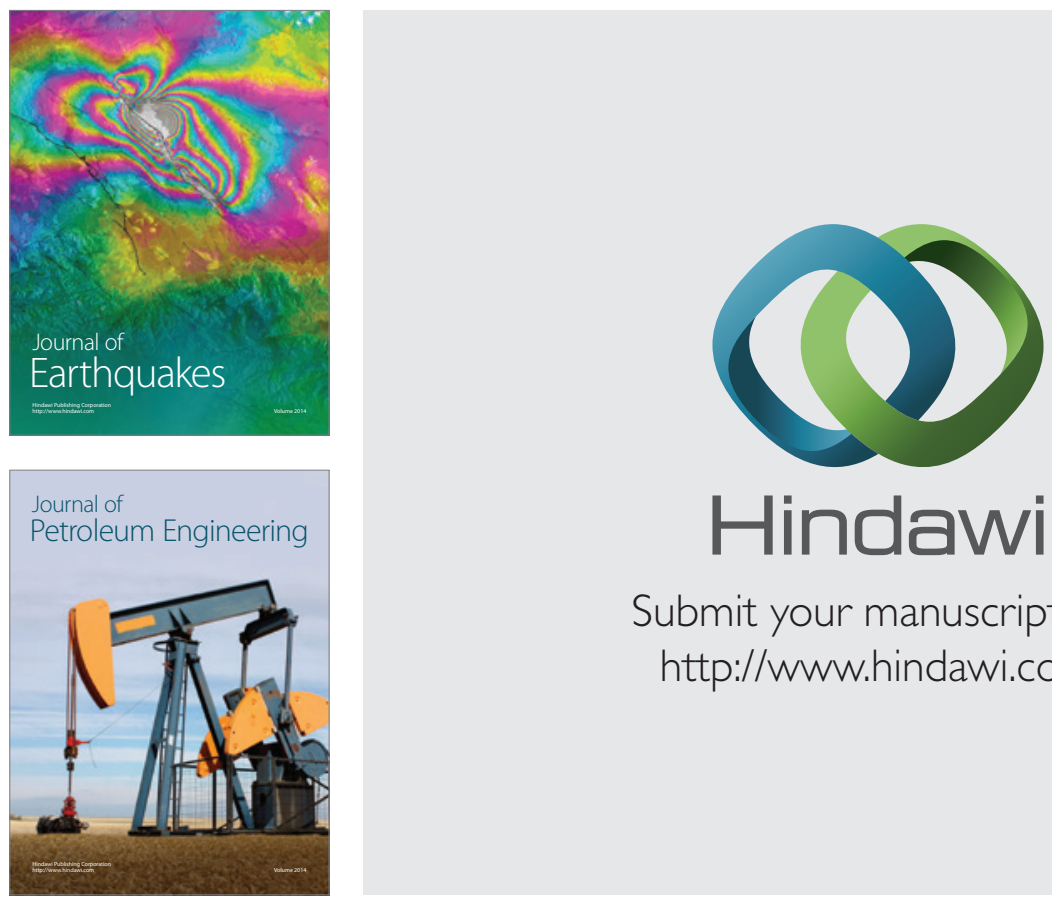

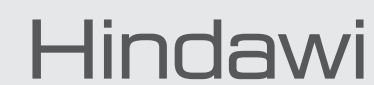

Submit your manuscripts at

http://www.hindawi.com
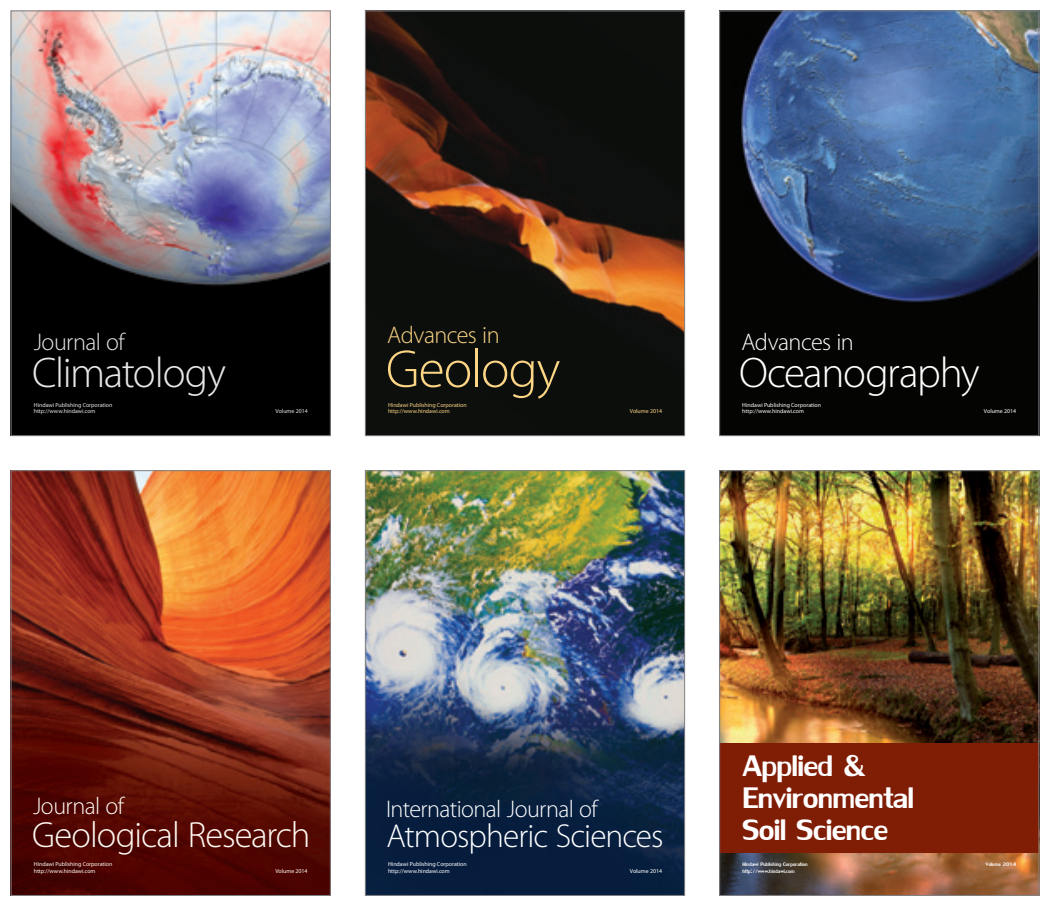
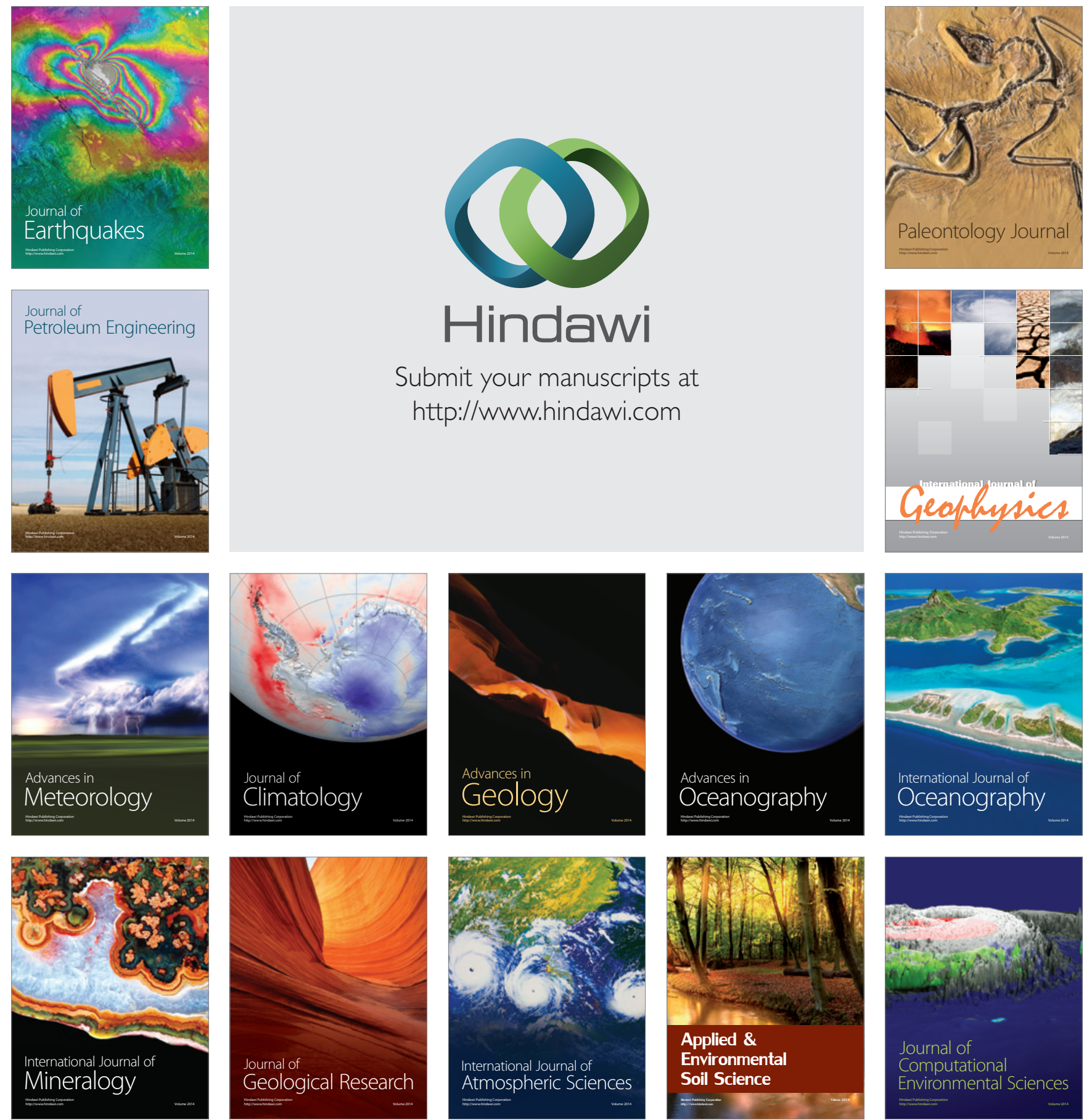